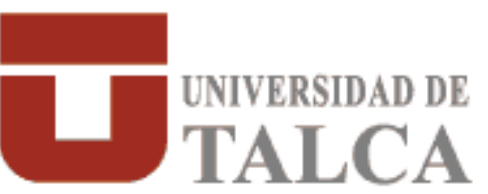

\title{
DETERMINACIÓN Y ESTUDIO DE ASOCIACIONES MICORRÍZICAS EN ESPECIES DE RHODOPHIALA
}

\section{ESTEBAN ALFONSO AGUAYO ROMERO INGENIERO AGRONÓMO}

\section{RESUMEN}

Las especies de Rhodophiala son plantas bulbosas nativas con potencial uso ornamental como plantas en maceta o de jardín. Son originarias de Chile, Bolivia, Argentina y Uruguay. En Chile, se distribuyen entre la II y $X$ región (Schiappacasse et al., 2002). Algunas se encuentran creciendo y desarrollando exitosamente bajo climas extremos y en suelos cuyas propiedades físico-químicas, hídricas y nutricionales son muy limitadas. Su grado de adaptación a diferentes condiciones ambientales es asombroso; pues, muchas veces viven en poblaciones extensas y relativamente densas por ejemplo en el desierto de Atacama, uno de los más secos de la Tierra (Hoffmann, 1989). Por estas razones estas especies han desarrollado asociaciones simbióticas con hongos, formando micorrizas que las ayudaría a completar su ciclo de vida bajo períodos de estrés y a sobrevivir en ambientes áridos como por ejemplo el de la III región (Dhillion et al., 1995). Es de interés comprobar la presencia de Rhodophiala spp. micorrizadas, en otras zonas del país menos restrictivas desde el punto de vista medio ambiental. Para ello se escogieron las especies R. splendens, R. bagnoldii y R. phycelloides, determinándose diferentes lugares para la recolección del material vegetal (bulbos con raíces) y suelo. En laboratorio, a través de la tinción de raíces se determinó la presencia de micorrizas vesículo-arbúsculares, superando el $70 \%$ de muestras micorrizadas en todas las especies. Posteriormente, para determinar el origen de la micorrización se sembraron semillas de R. splendens y R. phycelloides pregerminadas con y sin desinfección en suelos provenientes del hábitat natural no esterilizados y esterilizados en autoclave. Sólo se encontraron raíces micorrizadas en plántulas cultivadas en suelo sin esterilizar. Adicionalmente, mediante evaluaciones de materia seca, días a emergencia, diámetro de bulbos y longitud de raíces y hojas, se determinó que la 
esterilización del suelo y la desinfección de semillas en R. phycelloides y $R$. splendens, sólo afectó la longitud de raíces, pero además en esta última, también afectó el diámetro ecuatorial de bulbos producidos. En ambos casos, los mayores promedios obtenidos fueron en aquellos tratamientos con suelo no esterilizado. La esterilización del suelo (independiente de la desinfección o no de semillas) en ambas especies, no alteró los días a emergencia ni la longitud de sus hojas: sin embargo, en R. phycelloides sí alteró el diámetro ecuatorial de bulbos y la materia seca producida, cuyos valores fueron mayores en plantas cultivadas en suelo no esterilizado, en comparación a las cultivadas en suelo estéril. La desinfección de semillas no alteró ninguno de los parámetros de crecimiento medidos. 


\section{ABSTRACT}

Rhodophiala species are native plants bulbs with potential use as ornamental potted plants or in gardens. They come from Chile, Bolivia, Argentina and Uruguay. In Chile, they are distributed among the 2nd and 10th regions (Schiappacasse et al., 2002). Some of them are grown and developed successfully under extreme climates and soils which physico-chemical, water and nutritional conditions are very limited. Their adaptation degree to different environmental conditions is amazing, because, sometimes they live in large towns and relatively dense for example in the Atacama Desert, one of the driest deserts on Earth (Hoffmann, 1989). For these reasons, these species have developed symbiotic associations with fungi, forming mycorrhizal that would complement its life cycle under periods of stress and survive in arid environments such as the 3rd region (Dhillion et al., 1995). It is interesting to verify the presence of Rhodophiala spp. mycorrhizal in other less restrictive parts of the country in terms of environmental matters. For that reason, species R. splendens, R. bagnoldii and R. phycelloides were chosen, taking different places for the collection of plant material (bulbs with roots) and soil. In the laboratory, through the roots of staining was determined the presence of vesicular arbuscular mycorrhizae, getting over the $70 \%$ of samples mycorrhizal in all species. Subsequently, to determine the origin of the mycorrhization pregerminated seeds of R. splendens and R. phycelloides were sown with and without disinfection in soils natural habitat not sterilized and sterilized in an autoclave. Only mycorrhizal roots were found in seedlings grown in non-sterilized soil. Additionally, through assessments of dry matter, emergency days, bulbs diameter and length of roots and leaves, it was determined that the soil sterilization and disinfection of seeds in R. phycelloides and R. splendens, only affected the length of roots, but also in the last one, it affected the equatorial diameter of bulbs produced. In both cases, the major averages in those treatments were not sterilized soil. The soil sterilization (either disinfected and not disinfected seeds) in both species, did not alter the emergency days or the length of their leaves; however, in R. phycelloides it altered the equatorial diameter of bulbs and dry matter produced, which values were higher in plants grown in soil not sterilized, compared to those grown in sterile soil. The disinfection of seeds did not alter any of the parameters measured growth. 